\title{
Biological activity of peptides purified from fish skin hydrolysates
}

\author{
Racheal Abuine, Anuruddhika Udayangani Rathnayake and Hee-Guk Byun * (D)
}

\begin{abstract}
Fish skin waste accounts for part of the solid waste generated from seafood processing. Utilization of fish skin by bioconversion into high-grade products would potentially reduce pollution and economic cost associated with treating fish processing waste. Fish skin is an abundant supply of gelatin and collagen which can be hydrolyzed to produce bioactive peptides of 2-20 amino acid sequences. Bioactivity of peptides purified from fish skin includes a range of activities such as antihypertensive, anti-oxidative, antimicrobial, neuroprotection, antihyperglycemic, and anti-aging. Fish skin acts as a physical barrier and chemical barrier through antimicrobial peptide innate immune action and other functional peptides. Small peptides have been demonstrated to possess biological activities which are based on their amino acid composition and sequence. Fish skin-derived peptides contain a high content of hydrophobic amino acids which contribute to the antioxidant and angiotensin-converting enzyme inhibitory activity. The peptide-specific composition and sequence discussed in this review can be potentially utilized in the development of pharmaceutical and nutraceutical products.
\end{abstract}

Keywords: Fish skin, Peptides, Bioactivity, Antioxidant, Antihypertensive, Antimicrobial, Anti-Alzheimer's

\section{Background}

The marine environment is a source of functional biomaterials such as polyunsaturated fatty acids (PUFAs), polysaccharides, minerals and vitamins, antioxidants, enzymes, and bioactive peptides (Kim and Wijesekara 2010; Kim et al. 2008; Pomponi 1999). By-products of marine processing industries, i.e., skin, trimmings, viscera, and blood, contain a good amount of proteins which can be used as a source for bioactive peptides. These by-products are utilized as additives in animal husbandry as animal feed or in agriculture as fertilizers (Chalamaiah et al. 2012). Fish by-products like skin and frame need to be processed into fish hydrolysates either by fermentation or by hydrolysis techniques before they can be effectively utilized. By so doing this increases production costs (Chalamaiah et al. 2012). Therefore, the utilization of fish processing waste through bioconversion into high-grade products like bioactive peptides would be a better alternative. This not only would in-

\footnotetext{
* Correspondence: hgbyun@gwnu.ac.kr

Department of Marine Biotechnology, Gangneung-Wonju National University, Gangneung 25457, Republic of Korea
}

crease the economic value of the catch but also would reduce the amount of marine processing waste. Thus, reducing pollution and economic cost associated with treating the generated waste (Fang et al. 2017).

Biological activity of peptides is based on their amino acid composition and sequence (Pihlanto-Leppälä 2000). This biological activity ranges from antioxidant, antihypertensive, immunomodulatory, and antimicrobial activity as demonstrated by several studies using different fish species like Pollack, skate, Nile tilapia, sea beam, yellow fish, and skipjack (Chalamaiah et al. 2012). Bioactive peptides are specific protein fragments derived from plants or animal sources which possess nutritional benefits and positively influence health (Hartmann and Meisel 2007; Korhonen and Pihlanto 2003). Bioactive peptides are inactive in their parent protein sequence but can be released by enzymatic hydrolysis; however, for effective use, bioactive peptides must reach the target organ or receptors in the intestinal lumen intact and must survive enzymatic degradation (Adessi and Soto 2002). This review will highlight and discuss the different preparation methods of bioactive peptides from fish skin, their biological activity, and associated mode of action in regard to specific peptide composition, sequence, and cell signaling pathways.

(c) The Author(s). 2019 Open Access This article is distributed under the terms of the Creative Commons Attribution 4.0 International License (http://creativecommons.org/licenses/by/4.0/), which permits unrestricted use, distribution, and 


\section{Preparation of bioactive peptides from fish skin}

Fish protein hydrolysates contain peptides of 2-20 amino acid sequences after hydrolysis, and these peptides usually have biological activity. Several extraction methods are utilized to liberate bioactive peptides from the parent protein, and these include acid-alkaline hydrolysis: extracting collagen by using acidic or alkaline reagent; enzymatic hydrolysis: using enzymes to hydrolyze fish skin; and fermentation method: using microorganisms as a source of the enzymes (Huang et al. 2015).

\section{Enzymatic hydrolysis}

Enzymatic hydrolysis is the best way to hydrolyze fish skin without losing nutritional value (Huang et al. 2015). The method is preferred especially in the food and pharmaceutical industries because the hydrolysis process does not leave residual organic solvents or toxic chemicals in its products (Kim and Wijesekara 2010). Steps in enzymatic hydrolysis involve substrate preparation, choice of the right enzyme, measuring the extent of enzymatic hydrolysis, homogenization, and heating to inactivate endogenous enzymes, hydrolysis, and termination of the enzymatic reaction. Commercial enzymes such as alcalase, trypsin, pepsin, papain, pancreatin, and thermolysin are employed in the enzymatic hydrolysis (Bernardini et al. 2011). Conditions like enzyme concentration, $\mathrm{pH}$, time, and temperature have to be well monitored and maintained during hydrolysis. Enzyme concentrations, $\mathrm{pH}$, and temperature vary with the type of enzyme used. Enzyme concentrations of $0.01-5.00 \%$ $(w / w)$ and $\mathrm{pH}$ range of $1.5-11$ have been documented (Halim et al. 2016). Black-barred halfbeak gelatin was dissolved in DW and subjected to enzymatic hydrolysis with an enzyme/substrate ratio of 30:1, $\mathrm{pH} 10.0$ and $50^{\circ}$ C. The enzymatic activity was evaluated by a method described by (Kembhavi et al. 1993) using casein as a substrate. The gelatin solution was equilibrated for $30 \mathrm{~min}$ before the enzyme addition. The $\mathrm{pH}$ was maintained by addition of $2 \mathrm{~N} \mathrm{NaOH}$, and after $3 \mathrm{~h}$, the enzymes were inactivated by heating the solution at $95^{\circ} \mathrm{C}$ for $20 \mathrm{~min}$ (Abdelhedi et al. 2017). Extraction of pepsin soluble collagen (PSC) from fish skin was performed by (Mahboob 2014). Undissolved residue obtained after acid soluble collagen (ASC) extraction was utilized for the PSC extraction as described by (Singh et al. 2011).

\section{Acid-alkaline hydrolysis}

During fish skin hydrolysis by acid-alkaline hydrolysis, certain amino acids, i.e., tryptophan, serine, and threonine, can be destroyed at high $\mathrm{pH}$. Therefore, the $\mathrm{pH}$ and temperature of the hydrolysates must be closely observed during the hydrolysis process. Collagen extraction from fish skin by acid-alkaline hydrolysis involves treatment of pre-cleaned skin samples with an alkali $(\mathrm{NaOH})$ as an initial extraction step. The step is followed by continuous stirring at a controlled temperature for a set time. The procedure is repeated about 3 times, and it is carried out with an aim to remove non-collagenous proteins and pigments (Jong)areonrak et al. 2005; Wang et al. 2008; Wang et al. 2015). The skin is alternatively treated with an acid (HCl) (Wu et al. 2017). After acid-alkali treatment, the skin was washed to neutralize the $\mathrm{pH}$ and further extraction carried out with distilled water at $65^{\circ} \mathrm{C}$ for $4 \mathrm{~h}$. Some extraction procedures include a defatting step (Mahboob 2014). Jongjareonrak et al. 2005 removed fat using butyl alcohol for 24-48 h with gentle stirring and a change of solution every $8 \mathrm{~h}$. The resultant matter was then subjected to acid treatment with acetic acid for $24 \mathrm{~h}$ with gentle stirring. Collagen was extracted from fish skin, scale, and bone using a procedure described as follows (Wang et al. 2008). The collagen was extracted with $0.5 \mathrm{M}$ acetic acid at a sample/solution ratio of $1: 100(w / v)$ for $24 \mathrm{~h}$ with continuous stirring. The extracts were centrifuged at 20,000 $g$ for $1 \mathrm{~h}$ at $4{ }^{\circ} \mathrm{C}$, and the extraction step was repeated using the obtained residue, followed by centrifugation under the same conditions. The supernatants of the two extracts were combined and precipitated by the addition of $\mathrm{NaCl}$ to a final concentration of $0.9 \mathrm{M}$ and centrifuged at $2500 \mathrm{~g}$ for $0.5 \mathrm{~h}$ to obtain a precipitate that was dissolved in $0.5 \mathrm{M}$ acetic acid. The precipitate was dialyzed for $48 \mathrm{~h}$ against 10 volumes of $0.1 \mathrm{M}$ acetic acid and distilled water, respectively, which were changed every $8 \mathrm{~h}$, before being lyophilized. Antimicrobial peptides were purified from winter flounder epidermis and mucus extracts (Cole et al. 1997). The mucus was obtained from the skin by scraping and further subjected to homogenization in a solution of $50 \mathrm{ml}$ of $0.2 \mathrm{M}$ sodium acetate, $0.2 \%$ Triton $\mathrm{X}-100$, and $1 \mathrm{mM}$ phenyl methyl sulfonyl fluoride. The homogenate was centrifuged for $20 \mathrm{~min}$ at $20,000 \mathrm{~g}$, and the resultant supernatant was further purified.

\section{Fermentation}

Fermentation is considered a more natural method of protein hydrolysis. The technique has been employed for centuries especially in East Asian countries as a traditional preservation method. Fermentation not only enhances the flavor and taste of food but also increases its nutraceutical value. During the fermentation process, bioactive peptides are released by the action of both microorganisms and endogenous proteolytic enzymes. Several studies have demonstrated the bioactivity of various marine products like Thai fermented shrimp paste, shrimp by-products, squid miso, and a variety of traditional fermented fish products (Bueno-Solano et al. 2009; Giri et al. 2011; Kleekayai et al. 2015). Majumdar et al. 2016 examined the chemical and microbial properties of shidal, a traditional fermented fish product of Northeast India. A combination of both fatty acids 
(eicosapentaenoic, docosahexaenoic, arachidonic, linolenic, and linoleic acid) and proteins or peptides of MW (molecular weight) range between 45 and $29 \mathrm{kDa}$ and 45 and $6 \mathrm{kDa}$ respectively were reported to be present in the fermented fish product. Hydrolysates were prepared from turbot skin by utilization of the fermentation method using 3 microorganisms, i.e., Saccharomyces cerevisiae, Aspergillus oryzae, and Streptococcus thermophiles (Fang et al. 2017).

\section{Purification of peptides}

The biological activity of peptides is determined by properties like molecular weight, charge, and hydrophobicity. Therefore, peptides are purified through a multi-step purification process based on such properties. Purification based on molecular weight employs methods like ultrafiltration (UF), nanofiltration (NF), and gel filtration (GF) (Halim et al. 2016). Ion exchange chromatography (IEC) is used to fractionate peptides basing on their net charge. Fractioned peptides are then further purified using technologies like reversed-phase HPLC which separates compounds based on hydrophobicity and hydrophilicity (Conlon 2007). Peptide sequences of the most active fractions from HPLC analysis are then analyzed and identified using mass spectrometry methods like matrix-assisted laser deionization time-of-flight (MALDI-TOF), electrospray ionization mass (ESI), matrix-assisted laser desorption/ionization mass spectrometry (MALDI-MS), etc. (Bernardini et al. 2011).

\section{Biological activities}

\section{Antihypertensive activity}

Hypertension is a chronic condition affecting millions of people around the world. According to a report by World Health Organization 2011, the global prevalence of hypertension among adults $\geq 25$ years stands at $40 \%$ and it is estimated that 1.56 billion people will have the condition by 2025 (Kearney et al. 2005). Blood pressure is regulated by the renin-angiotensin-aldosterone system (RAS). Low renal blood flow or low plasma sodium concentration initiates the conversion of pro-renin into renin in juxtaglomerular cells in the kidneys. Renin in circulation catalyzes the conversion of angiotensinogen to angiotensin I which is then subsequently converted to angiotensin II by the enzyme angiotensin-converting enzyme (ACE) (Paul 2006). ACE is mainly produced in the lungs and other sites including the endothelial lining of vascular tissues, heart, brain, kidney, placenta, bone marrow, pancreas, and testis. Angiotensin II is a potent vasoconstrictor that causes blood vessels to narrow resulting in increased blood pressure (Rogerson et al. 1992). Simultaneously, it stimulates the secretion of the hormone aldosterone from the adrenal cortex causing the renal tubules to increase the reabsorption of sodium and water into the blood, while at the same time causing the excretion of potassium. Inhibition of ACE diminishes angiotensin II-mediated aldosterone secretion from the adrenal cortex, leading to a decrease in water and sodium reabsorption and a reduction in extracellular volume sequentially leading to vasodilation and eventually reduced arterial blood pressure. Hypertension is manageable with various synthetic ACE inhibitors such as captopril (Dezsi 2000). Hypertension can also be counteracted by endothelial-dependent vasodilation through the upregulation of nitric oxide (NO) expression, phosphorylation of eNOS, and downregulation of endothelin (ET-1) expression. Endothelial smooth muscle cell relaxation is achieved via the nitric oxide/ cyclic guanosine monophosphate (cGMP)-mediated intracellular signaling pathway. This pathway involves the upregulation of cGMP-dependent protein kinase I (cGK-I) and a decrease in intracellular calcium levels via downregulation of the inositol-1,4,5-trisphosphate (IP 3) receptor (Daiber and Münzel 2015).

Conventional antihypertensive drugs cause several adverse effects; therefore, the search for safer natural alternatives is in progress. Among the natural alternatives, interest has grown in the utilization of bioactive peptides in the prevention of hypertension and in the initial treatment of mild hypertension (Guang and Phillips 2009). The antihypertensive activity of fish skin peptides is discussed and summarized below in Table 1 .

Ultrafiltration of steelhead/rainbow hydrolysates yielded fractions of less than $3 \mathrm{kDa}$ with ACE inhibitory activity higher than the activity of the whole hydrolysates (Cheung and Li-Chan 2017). The low MW fractions were prepared from whole hydrolysates using commercial enzyme kits. Two fractions showed ACE inhibition activity of $54 \%$ and $63 \%$. The ACE inhibitory activity was affected by different conditions suggesting that the additional hydrolysis achieved with higher enzyme concentration and longer duration effectively generated shorter peptides with higher activity. The highest ACE inhibition was demonstrated in samples produced after $6 \mathrm{~h}$ hydrolysis with $4 \%$ protease. Similarly, fish skin peptide bioactivity has been shown to be associated with low MW peptides (Iwaniak et al. 2014; Power et al. 2014).

Black-barred halfbeak (Hemiramphus far) skin showed high protein content in the gelatin extracts, estimated at 91.36\% (Abdelhedi et al. 2017). The protein quantity in the gelatin was closely similar to that obtained in other fish skin species such as splendid squid, cuttlefish, thornback ray, and cobia (Jridi et al. 2013; Lassoued et al. 2014; Nagarajan et al. 2012; Silva et al. 2014). The ACE inhibitory activity was $36.51 \%$ for $1 \mathrm{mg} / \mathrm{mL}$ of whole gelatin while $1 \mathrm{mg} / \mathrm{mL}$ gelatin hydrolysate showed a significantly greater activity of $80.76 \%$. However, these values were significantly lower than the positive control 
Table 1 ACE inhibitory activity peptides purified from fish skin hydrolysates

\begin{tabular}{|c|c|c|c|}
\hline Species & $I C_{50}(\mu \mathrm{M})$ & Peptide sequence & Reference \\
\hline Nile tilapia (Oreochromis niloticus) & $760-1490$ & GIV, GAP*GF, GFA*GPA, SGNIGFP*GPK, GIPGPIGPP*GRP & Thuanthong et al. (2017) \\
\hline \multirow[t]{2}{*}{ Pacific cod skin } & 6.9 & GASSGMPG & Ngo et al. (2016) \\
\hline & 14.5 & LAYA & \\
\hline \multirow[t]{2}{*}{ Thornback ray skin } & 27.9 & GIPGAP & Lassoued et al. (2015) \\
\hline & 170 & APGAP & \\
\hline \multirow[t]{2}{*}{ Skate } & 3.09 & MVGSAPGVL & Ngo et al. (2014b) \\
\hline & 4.22 & LGPLGHQ & \\
\hline Salmon (Oncorhynchus keta) & 8.7 & GLPLNLP & Lee et al. (2014) \\
\hline \multirow[t]{2}{*}{ Skate } & 95 & PGPLGLTGP & Lee et al. (2011) \\
\hline & 148 & QLGFLGPR & \\
\hline \multirow[t]{2}{*}{ Alaska pollock } & 2.6 & GPL & Byun and Kim (2002) \\
\hline & 17.13 & GPM & \\
\hline Cod (Gadus microcephalus) & - & TCSP, TGGGNV & Ngo et al. (2011) \\
\hline
\end{tabular}

captopril. The hydrolysate had an ACE inhibitory $\mathrm{IC}_{50}$ value of $332.66 \pm 16.57 \mathrm{mg} / \mathrm{mL}$. Higher values of ACE inhibitory activity of hydrolysate in comparison to those of the gelatin are an indicator that bioactive peptides are released from the protein molecules upon enzymatic hydrolysis (Abdelhedi et al. 2017). In another study, five novel ACE inhibitory peptides GIV, GAP*GF, GFP*GPA, SGNIGFP*GPK, GIPGPIGPP*GPR were identified from the most active fractions of Nile tilapia skin gelatin. The $\mathrm{IC}_{50}$ value of the active peptides ranged between 760 and $1490 \mu \mathrm{M}$ (Thuanthong et al. 2017).

Pacific cod skin gelatin was hydrolyzed using several enzymes and the pepsin hydrolysate showed the highest ACE inhibitory effect of about 91\% (Ngo et al. 2016). ACE inhibitory active peptides were identified as GASSGMPG, IC $\mathrm{IC}_{50} 6.9 \mu \mathrm{M}$, and LAYA, $\mathrm{IC}_{50} 14.5 \mu \mathrm{M}$. The MW of peptides GASSGMPG and LAYA was less than $1 \mathrm{kDa}$ which indicates they can cross the intestinal barrier and exert biological effects. The ACE inhibitory activity of GASSGMPG was higher than that of ASL, $\mathrm{IC}_{50} 102.15 \mu \mathrm{M}$ from silkworm pupa (Bombyx mori) protein; PVNNPQIH, IC $\mathrm{I}_{50} 206.7 \mu \mathrm{M}$ from small red bean Phaseolus vulgaris; GDLGK-TTTVSNWSPPKYKDTP, $\mathrm{IC}_{50} 11.28 \mu \mathrm{M}$ from tuna frame protein; and AHEPVK, $\mathrm{IC}_{50} 63 \mu \mathrm{M}$ from edible mushroom Agaricus bisporus (Lau et al. 2014; Lee et al. 2010; Rui et al. 2013; Wu et al. 2015). A docking simulation of the ACE-ligand complexes between ACE/peptides and ACE/captopril demonstrated the potential of these peptides as ACE inhibitors. The binding sites of GASSGMPG and captopril on the ACE molecule were observed to be the same at the Asn72 residue while LAYA and captopril shared two binding sites on the ACE molecule at Asn72 and Arg348 residues. Overall molecular docking simulation demonstrated good protein-drug interaction which can be attributed to factors such as Van der Waals force and hydrogen bonds of molecules that stabilize the ligandprotein.

Peptides IGPAG, FGYGG, GIPGAP, IGAPGATGPAG, AKGDS, GASGPRGPA, GQDGRPGPAG, and GEAGNPGPAGP were purified from Thornback ray skin gelatin neutrase hydrolysate (Lassoued et al. 2015). Peptide GIPGAP, $\mathrm{IC}_{50} 27.9 \mu \mathrm{M}$, was the most potent ACE inhibitor among the purified peptides. A hydrolysate TRGH-A26 was prepared using crude proteases from Bacillus subtilis A26, and peptides AVGAT, GGVGR, APGAP, GEPGAPGPA, and GPRGAPGPA were purified. The peptide APGAP, IC 50 $170 \mu \mathrm{M}$, was the most potent ACE inhibitor from this hydrolysate. The two most potent peptides GIPGAP and APGAP from Thornback ray skin gelatin hydrolysates had a strikingly similar sequence of PGAP at the C-terminus. Another peptide FGYGG with a high ACE inhibitory activity with an $\mathrm{IC}_{50}$ value of $231 \mu \mathrm{M}$ contained the aromatic residue phenylalanine.

The antihypertensive effect of skate skin hydrolysates in an animal model experiment using spontaneously hypertensive rats (SHRs) was evaluated (Ngo et al. 2014b). Purified peptides were orally administered to SHRs, and changes in heart rate and blood pressure were monitored over a period of 20 days. Systolic blood pressure readings were monitored, and the maximal decrements in systolic blood pressure observed were 127.2 $\mathrm{mmHg}$ at 20 days and $118.8 \mathrm{mmHg}$ at 10 days in the purified peptide $(1000 \mathrm{mg} / \mathrm{kg}$ of BW) and captopril treatment groups respectively. The peptides were identified as MVGSAPGVL, IC $\mathrm{I}_{50} 3.09 \mu \mathrm{M}$, and LGPLGHQ, $\mathrm{IC}_{50}$ $4.22 \mu \mathrm{M}$. Docking simulation of the ACE molecule and the purified peptide on the Docking Server revealed almost similar binding on the ACE molecule as captopril. The binding site between the ACE molecule and the 
purified peptide had many residues including Trp67, Asn68, Thr71, Asn72, and Arg348. This suggested that blockades by the purified peptides on the ACE molecule may contribute to the ACE inhibitory potency of the purified peptides for preventing hypertension.

Furthermore, the protective effect of the same peptides MVGSAPGVL and LGPLGHQ from skate skin peptides was investigated against angiotensin II-induced endothelial dysfunction using human endothelial cells (Ngo et al. 2014a). Increased production of endothelial nitric oxide synthase (eNOS) and inhibition of endothelin-1 ET-1 production through upregulation of the PPAR- $\gamma$ pathway was observed. The enzyme eNOS upregulates the generation of nitric oxide $(\mathrm{NO})$ in the vascular endothelium while NO maintains endothelial integrity and proper function through regulation of vascular tone, local blood flow, platelet aggregation and adhesion, and leukocyteendothelial cell interactions (Dessy and Feron 2004). Thus, endothelial dysfunction, a precursor of hypertension and other health conditions like diabetes, aging, and atherosclerosis, results from abnormalities in NO production by the vascular endothelium. Purified peptides from skate skin not only showed ACE inhibitory activity but also provided protection against endothelial dysfunction in endothelial cells. Other peptides with ACE inhibitory activity purified from similar studies include PGPLGLTGP, IC $5095 \mu \mathrm{M}$, and QLGFLGPR, IC 50 $148 \mu \mathrm{M}$, from skate skin; GLPLNLP, $\mathrm{IC}_{50} 18.7 \mu \mathrm{M}$, from salmon skin; and GPL, IC $\mathrm{IC}_{50} 2.6 \mu \mathrm{M}$, and $\mathrm{GPM}, \mathrm{IC}_{50}$ $17.13 \mu \mathrm{M}$, from Alaska Pollock skin (Byun and Kim 2002; Lee et al. 2014; Lee et al. 2011).

Typically, ACE inhibitory has been attributed to smallsized peptide residues with 2-12 amino acids (Yamamoto et al. 1994). Peptides with tryptophan, proline, or phenylalanine at the $\mathrm{C}$-terminus or branched-chain aliphatic amino acids at the $\mathrm{N}$-terminus are suitable to act as competitive inhibitors of ACE (Cushman and Cheung 1971). Many of the peptides identified in ACE inhibitory fractions contain proline at one of the three $\mathrm{C}$-terminal positions. Hydrophobic amino acids in the $\mathrm{N}$-terminus may also contribute to the ACE inhibitory activity (Rho et al. 2009). Therefore, in addition to the presence of proline in the C-terminal position, the presence of alanine could also be a contributing factor to ACE inhibitory activity (Yamamoto et al. 1994). Natural ACE inhibitory peptides and ACE substrates such as bradykinin and angiotensin I have been shown to contain aromatic amino acid residues such as phenylalanine (Camargo et al. 2012; Cheung et al. 1980; Hara et al. 1984). Peptides inhibiting ACE activity can potentially be used as nutraceuticals to lower elevated blood pressure. As described, ACE inhibitory peptides have been successfully purified from fish skin and their biological activity has been demonstrated by both in vitro and in vivo studies.

\section{Antioxidant activity}

Reactive oxygen species (ROS) and reactive nitrogen species (RNS) are produced as a result of the metabolism of oxygen and nitrogen. ROS and RNS can cause damage to cellular components in the body. During metabolism and respiration, ROS are constantly produced. These include superoxide anion radials $\mathrm{O}_{2}^{-}$, hydroxyl radical $\mathrm{OH}^{-}$, and non-free radical species like hydrogen peroxide and singlet oxygen ${ }^{1} \mathrm{O}_{2}$. Excess amounts of ROS as in oxidative stress exert oxidative damage to cellular macromolecules like proteins, lipids, and DNA by subtracting electrons. This starts a series of reactions which eventually leads to new radicals attacking and damaging other cellular macromolecule components (Kaur and Kapoor 2001). Peptides are considered to be more potent antioxidants than free amino acids because of the increased stability of the resultant peptide radical (Elias et al. 2008). The exact structure-antioxidant activity relationship of peptides has not been established. However, the type, position, and hydrophobicity of amino acids in the peptides are considered to play an essential role. The most reactive amino acids in proteins are usually those with nucleophilic sulfur-containing side chains like taurine, cysteine, and methionine or aromatic side chains like tryptophan, tyrosine, and phenylalanine (Elias et al. 2008). Fish skin is an abundant supply of gelatin and collagen. Gelatin contains an abundance of hydrophobic amino acids such as glycine, valine, alanine, proline, and hydroxyproline and could potentially contain a range of peptides with potent lipid-peroxidation inhibitory activity (Kim and Mendis 2006). Several methods are used for assessing antioxidant activity, and these include oxygen radical absorbance capacity (ORAC), Ferric-reducing antioxidant power (FRAP) and 2,2-diphenyl-1-picrylhydrazyl (DPPH). Low MW peptides have higher ORAC values and metal-chelating activities while high MW peptides have higher FRAP and DPPH radical scavenging (Theodore et al. 2008). The antioxidant activity of fish skin peptides is summarized in Table 2.

Abdelhedi et al. 2017 investigated the antioxidant activity of gelatin extract from black-barred halfbeak (Hemiramphus far) skin. The DPPH radical scavenging activities of the gelatin extract $(5 \mathrm{mg} / \mathrm{mL})$ and the positive control vitamin $\mathrm{C}$ were $43.39 \%$ and $70.0 \%$ respectively. The antioxidant activity was lower than that of the positive control. However, lower MW fish skin protein hydrolysates of cobia skin and Raja clavata skin have been demonstrated to show higher antioxidant activity than their protein molecule precursors (Lassoued et al. 2015). The ferric-reducing antioxidant power for whole gelatin, gelatin hydrolysate, and vitamin $\mathrm{C}$ was determined to be $0.47,1.03$, and 2.01 respectively. Whole gelatin and gelatin hydrolysate exhibited similar antioxidant activity using the $\beta$-carotene bleaching assay with activities of $53.73 \%$ and $78.47 \%$ respectively. 
Table 2 Anti-oxidative activity of peptides purified from fish skin

\begin{tabular}{|c|c|c|c|c|c|}
\hline \multirow[t]{2}{*}{ Species } & \multicolumn{3}{|c|}{ Radical scavenging activity $(\mu \mathrm{g} / \mathrm{mL})$} & \multirow[t]{2}{*}{ Peptide sequence } & \multirow[t]{2}{*}{ Reference } \\
\hline & $\mathrm{DPPH}$ & Hydroxyl (HO•) & ABTS & & \\
\hline Thornback ray & 1980 & - & - & AVGAT & Lassoued et al. (2015) \\
\hline Nile tilapia (Oreochromis niloticus) & $8.82 \mu \mathrm{M}$ & $7.56 \mu \mathrm{M}$ & - & DPALATEPDMPF & Ngo et al. (2010) \\
\hline Horse Mackerel (Magalaspis cordyla) & $72.3 \%$ & $51.2 \%$ & - & NHRYDR & $\begin{array}{l}\text { Sampath Kumar et al. } \\
\text { (2012) }\end{array}$ \\
\hline Crocker (Otolithes ruber) & $79.6 \%$ & $56.8 \%$ & - & GNRGFACRHA & $\begin{array}{l}\text { Sampath Kumar et al. } \\
\text { (2012) }\end{array}$ \\
\hline Hoki (Johnius belengerii) & $156.2 \mu \mathrm{M}$ & - & - & HGPLGPL & Mendis et al. (2005b) \\
\hline \multirow{3}{*}{$\begin{array}{l}\text { Blue leatherjacket (Navodon } \\
\text { septentrionalis) }\end{array}$} & 405 & 179 & - & GSGGL & \multirow[t]{3}{*}{ Chi et al. (2015) } \\
\hline & 194 & 89 & - & GPGGFI & \\
\hline & 118 & 73 & - & FIGP & \\
\hline \multirow[t]{4}{*}{ Seabass (Lates calcarifer) } & - & - & $81.41^{*}$ & GLFGPR & \multirow[t]{4}{*}{ Sae-Leaw et al. (2017) } \\
\hline & - & - & $10.4^{*}$ & GATGPQGPLGPR & \\
\hline & - & - & $2.59^{*}$ & VLGPF & \\
\hline & - & - & $0.50^{*}$ & QLGLGPV & \\
\hline \multirow[t]{2}{*}{ Jumbo squid (Dosidicus gigas) } & - & - & - & FDSGPAGVL & \multirow[t]{2}{*}{ Mendis et al. (2005a) } \\
\hline & - & - & - & DGPLQAGQPGER & \\
\hline Amur sturgeon & 5380 & 890 & 8 & PAGT & Nikoo et al. (2015) \\
\hline Cod (Gadus microcephalus) & - & - & - & TCSP, TGGGNV & Ngo et al. (2011) \\
\hline \multirow[t]{2}{*}{ Nile tilapia (Oreochromis niloticus) } & - & 4.61 & - & EGL & \multirow[t]{2}{*}{ Zhang et al. (2012) } \\
\hline & - & 6.45 & - & YGDEY & \\
\hline Pacific cod & \multicolumn{3}{|c|}{ Iron-chelating activity } & $\begin{array}{l}\text { GPAGPHGPPGKDGR, AGPHGPPGKDGR, } \\
\text { AGPAGPAGAR }\end{array}$ & Wu et al. (2017) \\
\hline
\end{tabular}

*Units in millimole TE per millimole peptide

Similar results have been recorded for thornback ray skin by (Lassoued et al. 2015). Whole gelatin, gelatin hydrolysates, and vitamin $\mathrm{C}$ inhibited the peroxidation of linoleic acid by $15.91 \%, 34.78 \%$, and $70.22 \%$ respectively after 3 days and $39.25 \%, 74.88 \%$, and $99.2 \%$ respectively after 9 days. Similarly, the gelatin hydrolysate from Nile tilapia skin exhibited $59.74 \%$ of lipid peroxidation inhibition after a 5-day incubation period while whole gelatin had activity of only 7.12\% (Choonpicharn et al. 2015). The authors noted that antioxidant activity observed could be due to the presence of hydrophobic amino acids. Other studies using black-barred and Acipenser schrenckii skin gelatin hydrolysates observed that glycine and proline had high antioxidant activity (Ngo et al. 2011; Nikoo et al. 2015).

The antioxidant activity of thornback ray gelatin hydrolysates was assayed using various in vitro tests (Lassoued et al. 2015). Hydrolysis was carried out using alcalase, neutrase, and Bacillus subtilis A26 proteases. A hydrolysate obtained by treatment with Bacillus subtilis A26 proteases (TRGH-A26) had a high DPPH scavenging activity with an $\mathrm{IC}_{50}$ value of $1.98 \mathrm{mg} / \mathrm{mL}$ and $\beta$-carotene bleaching inhibition activity of $70 \%$. The high content of positively charged amino acids lysine and histidine (16.83\%) in TRGH-A26 may be responsible for the high antioxidant activity (Carrasco-Castilla et al. 2012). The anti-oxidative efficacy of $180 \mathrm{~mol} / \mathrm{ml} \alpha$ tocopherol equivalents at $5 \mathrm{mg} / \mathrm{mL}$ in the phosphomolybdenum assay was also evaluated and TRGH-A26 exhibited the highest anti-oxidative efficacy. TRGH-alcalase gelatin hydrolysate was the most potent inhibitor of DNA oxidation by hydroxyl radicals. Likewise, it also demonstrated DNA protective effect as no degradations were observed for the two forms of plasmid DNA utilized in the test. DNA oxidation inhibition activity may be attributed to hydrophobic amino acids which were present in TRGH-alcalase and TRGH-neutrase peptide hydrolysates. Amino acids histidine, tyrosine, methionine, and phenylalanine were high in TRGH-A26 and TRGH-Crude at total percentages of 13.22 and $13.09 \%$, respectively.

Nile tilapia (Oreochromis. niloticus) scale gelatin protein was hydrolyzed using alcalase, pronase E, trypsin, and pepsin (Ngo et al. 2010). A peptide purified from the alcalase hydrolysate provided significant protection against the DNA oxidative damage when exposed to $\mathrm{OH}$ generated by $\mathrm{Fe}^{2+} / \mathrm{H}_{2} \mathrm{O}_{2}$. The DNA damage was inhibited by about $70 \%$. The cell viability tests using mouse macrophages (RAW 264.7) and human lung fibroblasts 
(MRC-5) confirmed that gelatin alcalase hydrolysate was non-cytotoxic. The purified peptide was identified as DPALATEPDMPF. The ROS scavenging activity was determined using a fluorescence probe, $2^{\prime}, 7^{\prime}$-dichlorofluorescin diacetate (DCFH-DA). DCFH reacts with ROS to form a highly fluorescent compound DCF. Pre-treatment with the purified peptide decreased the DCF fluoresce in a time-dependent manner. The antioxidant activity of the purified peptide could be attributed to the presence of several amino acids, such as tyrosine, methionine, lysine, and tryptophan. The peptide sequence analysis showed high hydrophobic amino acid content $(>69 \%)$. The activity of the purified Nile tilapia (O. niloticus) scale gelatin peptide could be attributed to the presence of non-aromatic amino acids such as alanine, proline, valine, and leucine (Mendis et al. 2005a; Mendis et al. 2005b). Other peptides with anti-oxidative activity purified from fish skin have been purified from blue leatherjacket (Navodon septentrionalis), seabass (Lates calcarifer), horse mackerel (Magalaspis cordyla), crocker (Otolithes ruber), and Nile tilapia (Oreochromis niloticus) (Chi et al. 2015; Sae-Leaw et al. 2017; Sampath Kumar et al. 2012; Zhang et al. 2012).

Chelation of pre-oxidative transition metals like $\mathrm{Fe}^{+}$, $\mathrm{Cu}^{2+}$, and $\mathrm{Pb}^{2+}$ is another antioxidant mechanism. Therefore, peptides exhibiting metal-chelating activity are considered as potential antioxidants. Three novel iron-chelating peptides were purified from Pacific cod skin gelatin (Wu et al. 2017). The sequences of the purified peptides were identified as GPAGPHGPPGKDGR, AGPHGPPGKDGR, and AGPAGPAGAR. The iron-chelating ability was evaluated using ESI-MS and FTIR spectroscopy. The analysis showed that the amino and carboxylate terminal groups, peptide bonds from peptide backbone, amino, and imine from arginine side chain were involved in the formation of a complex with iron. Amino acid side chain groups of GPAG PHGPPGKDGR and AGPHGPPGKDGR, including amino (lysine), imine (histidine), and carboxylate (aspartic acid), provided additional iron-binding sites.

Scales of Lates calcarifer, Mugil cephalus, Chanos chanos, and Oreochromis spp. were hydrolyzed by papain and flavourzyme, and the $\mathrm{Fe} 2^{+}$-binding activity for the different species was compared (Huang et al. 2015). Ferrous ion together with collagen peptides from four fish scales was placed in a dialysis bag (MW cut off $500 \mathrm{Da}$ ) for 3-4 days of dialysis. A fraction from Chanos chanos had the highest iron-binding capacity at approximately $22.1 \mathrm{ppm} / \mathrm{mg}$ based on $\mathrm{Fe}^{+}$binding activity/peptide concentration. MW distributions of the collagen peptides from the scales of the four fish were all less than $10 \mathrm{kDa}$, with an average MW of $1.3 \mathrm{kDa}$. It is suggested that the iron-binding ability of peptides is related to the net charge and the exposure of glycine residues. Glycine is important for ferrous ions and peptides to form stable complexes (Lee and Song 2009; Wu et al. 2012). The
$\mathrm{Fe}^{+}$binding activity of fish scales is probably derived from the exposure of glycine during hydrolysis since fish scale collage is rich in glycine (Chaud et al. 2002; Fahmi et al. 2004). However, to fully understand the actual mechanism, more study is needed. Peptides purified from Alaska Pollock skin gelatin and jumbo squid (Dosidicus gigas) skin gelatin demonstrated a protective effect against oxidative stress in rat liver cells and human fibroblasts respectively (Byun and Kim 2002; Mendis et al. 2005b). While peptides from hoki skin (Johnius belengerii) gelatin showed protection against oxidative stress by upregulating the expression of antioxidant enzymes, i.e., glutathione peroxidase, catalase, and superoxide dismutase, in human hepatoma cells in vitro (Mendis et al. 2005b).

Peptides with antioxidant activities from marine sources with high radical scavenging antioxidant activity contained amino acids histidine, tyrosine and methionine (Saiga et al. 2003). While peptides containing amino acids histidine, glutamic acid, aspartic acid, phosphorylated serine, and threonine have been demonstrated to be active metal chelators. Amino acid methionine is considered as central in antioxidant activity, and its antioxidant mechanism is attributed to the action of two-electron transfer from the sulfide of methionine's thioester group (Garner et al. 1998). Last but not least, peptides with antioxidant activity also have potential anti-inflammatory activity, neuroprotective activity, and anti-allergy activity which in some cases it has been tested as with the neuroprotective effect of grass carp skin hydrolysates observed in MES 23.5 cells (Cai et al. 2015).

\section{Antimicrobial activity}

Fish live in an environment where a myriad of saprophytic and pathogenic microbes flourish putting them in constant direct contact with potential pathogens. Therefore, the fish skin acts a physical barrier by providing immediate protection from the environment and as a chemical barrier through several innate immune factors such as antimicrobial peptides (AMPs) (Bergsson et al. 2005). AMPS are low MW peptides that have a net positive charge and are amphiphilic. They are involved in the natural defense mechanism against pathogens (innate immunity); however, their main role is modulation of mammalian cell functions. AMPS can be majorly divided into different families which include defensin, parasin, cathelicidin and hepcidin, and piscidin. These AMP families are species-specific, with piscidin being unique to teleost fish (Campoverde et al. 2017). Table 3 outlines the specific MEC and MIC values for fish skin peptides with antimicrobial activity along with their sequences.

The antibacterial activity of black-barred halfbeak gelatin and its hydrolysate was evaluated against three Gram negative (Klebsiella pneumonia, Salmonella enterica, and Salmonella typhi) and three Gram positive (Micrococcus 
Table 3 Antimicrobial activity of peptides purified from fish skin

\begin{tabular}{|c|c|c|c|c|c|}
\hline Species & $\begin{array}{l}\text { MECs }(\mu \mathrm{g} / \\
\mathrm{mL})\end{array}$ & $\begin{array}{l}\mathrm{MIC}(\mu \mathrm{g} / \\
\mathrm{mL})\end{array}$ & Microorganism & Peptide sequence & Reference \\
\hline \multirow[t]{7}{*}{ Skipjack tuna (Katsuwonus pelamis) } & 3 & - & B. subtilis & \multirow[t]{7}{*}{ SJGAP } & \multirow[t]{7}{*}{ Seo et al. (2014) } \\
\hline & 26 & - & M. luteus & & \\
\hline & 4.8 & - & S. iniae & & \\
\hline & 25 & - & A. hydrophila & & \\
\hline & 2.7 & - & E. coli & & \\
\hline & 9 & - & V. parahaemolytics & & \\
\hline & 16 & - & C. albicans & & \\
\hline \multirow[t]{6}{*}{ Yellowfin tuna (Thunnus albacares) } & 1.2 & - & B. subtilis & \multirow[t]{6}{*}{ YFGAP } & \multirow[t]{6}{*}{ Seo et al. (2012) } \\
\hline & 6.5 & - & M. luteus & & \\
\hline & 17 & - & S. iniae & & \\
\hline & 8 & - & A. hydrophila & & \\
\hline & 3 & - & E. coli & & \\
\hline & 3.2 & - & V. parahaemolytics & & \\
\hline \multirow[t]{4}{*}{ Yellow catfish (Pelteobagrus fulvidraco) } & - & 2 & B. subtilis & \multirow[t]{4}{*}{ GKLNLFLSRLEILKLFVGA } & \multirow[t]{4}{*}{ Su (2011) } \\
\hline & - & 4 & S. aureus & & \\
\hline & - & 16 & E. coli & & \\
\hline & - & 64 & C. albicans & & \\
\hline \multirow{6}{*}{$\begin{array}{l}\text { Winter flounder (Pleuronectes } \\
\text { americanus) }\end{array}$} & - & $1.1-2.2 *$ & B. subtilis & \multirow[t]{6}{*}{ GWGSFFKKAAHVGKHVGKAALTHYL } & \multirow{6}{*}{$\begin{array}{l}\text { Cole et al. } \\
(1997)\end{array}$} \\
\hline & - & $4.4-8.8 *$ & P. haemolytica & & \\
\hline & - & $17.7-2.2^{*}$ & S. aureus & & \\
\hline & - & $2.2-3.3 *$ & E. coli & & \\
\hline & - & $8.8-17.7 *$ & $\begin{array}{l}\text { S. typhimurium (I and } \\
\text { II) }\end{array}$ & & \\
\hline & - & $17.7-35.0 *$ & A. salmonicida & & \\
\hline
\end{tabular}

*Units in micromolar

luteus, Staphylococcus aureus, and Bacillus cereus) bacteria (Abdelhedi et al. 2017). Black-barred halfbeak gelatin at 10 $\mathrm{mg} / \mathrm{mL}$ exhibited a slight inhibitory activity against Gram positive $M$. luteus and $B$. cereus, with inhibitor diameter zones of $6.5 \mathrm{~mm}$ and $7.0 \mathrm{~mm}$, respectively. Increasing concentration from 10 to $25 \mathrm{mg} / \mathrm{mL}$ slightly increased activity with inhibition zone diameter reaching $8.5 \mathrm{~mm}$ and $9.0 \mathrm{~mm}$ against $M$. luteus and $B$. cereus, respectively. The gelatin hydrolysate showed higher activity and was able to inhibit all the tested bacteria strains with different potentialities with $S$. aureus and B. cereus being the most sensitive. The positive control gentamicin was more potent against $S$. aureus and $B$. cereus, and it showed effective inhibition against the growth of all tested bacteria strains than the black-barred gelatin hydrolysate.

The antimicrobial activity of peptides purified from yellowfin tuna (Thunnus albacares) and skipjack tuna (Katsuwonus pelamis) skin was investigated (Seo et al. 2014; Seo et al. 2012). Two glyceraldehyde-3-phosphate dehydrogenase (GAPDH)-related AMPs, YFGAP and SJGAP, were identified. Both peptides showed broad-spectrum activity against Gram-positive and Gram-negative bacteria including three fish pathogens, Aeromonas hydrophila, Streptococcus iniae, and Vibrio parahaemolyticus. Antimicrobial activity of SJGAP and YFGAP showed MECs value of $1.2-17.0 \mu \mathrm{g} / \mathrm{mL}$ against Gram-positive bacteria while the MEC value against Gram-negative bacteria was $3.1-12.0 \mu \mathrm{g} / \mathrm{mL}$. The SJGAP peptide purified from skipjack tuna had a higher antimicrobial activity as it showed activity against Candida. Albicans with MEC value of $16.0 \mu \mathrm{g} / \mathrm{mL}$ unlike the peptide YFGAP purified from yellowfin tuna. These results suggest that these peptides might be related to the innate defense in tuna. Based on the secondary structure prediction and the homology modeling, the peptides formed an amphipathic structure and consisted of a $\beta-\alpha-\beta$ motif with three secondary structural motifs including one $\alpha$-helix, two parallel $\beta$-strands, and two loop regions. Sequence analysis results showed that both peptides, YFGAP and SJGAP, had high similarities with the $\mathrm{N}$-terminus of GAPDH from other fish species by $81-91 \%$ and $91-97 \%$ respectively. GAPDH is a multifunctional protein that regulates the sixth step of glycolysis and mediates cell death under oxidative stress as well. Involvement of GAPDH in nuclear translocation and its aggregation under oxidative 
stress have been proposed as processes leading to GAPDH-mediated cell death. Furthermore, oxidative stressors initiate amyloid-like GAPDH aggregation via intermolecular disulfide bonds at Cys-152 (Nakajima et al. 2017). However, the antimicrobial activity observed could be as a result of the peptides, YFGAP and SJGAP, acting as analogs of GAPDH in the sixth step of glycolysis due to high similarities with its $\mathrm{N}$-terminus.

Aside from hydrolysates, AMPs have also been successfully isolated from fish skin mucus as well. The antimicrobial activity of yellow catfish (Pelteobagrus fulvidraco) skin mucus was investigated, and a novel peptide GKLNL FLSRLEILKLFVGAL was identified and named pelteobagrin (Su 2011). Structural analysis using Schiffer-Edmundson helical wheel modeling revealed that pelteobagrin forms an amphipathic alpha-helix composed of 10 out of 12 hydrophobic residues on the surface and 4 out of 6 hydrophilic residues on the opposing side. The peptide had a positive charge +2 and was made up of $60 \%$ hydrophobic amino acids. It displayed a broad-spectrum antimicrobial activity against Gram-positive bacteria, Gram-negative bacteria, and fungi. However, Gram-positive bacteria B. subtilis was the most sensitive to the peptide at a minimal inhibition concentration (MIC) of $2 \mu \mathrm{g} / \mathrm{mL}$. The peptide demonstrated no hemolytic activity against rabbit red blood cells, and it was relatively salt tolerant to concentrations of $\mathrm{NaCl}$ up to $137 \mathrm{mM}$. Similarly, a novel peptide from skin mucous secretions of the winter flounder (Pleuronectes americanus) was purified and characterized (Cole et al. 1997). The peptide was named pleurocidin, and it had an amino acid sequence of GWGSFFKKAAHVGKHVGKAALTHYL. It exhibited a broad-spectrum activity against a wide range of Gram-positive and Gram-negative bacteria. Gram-positive bacteria $B$. subtilis was the most sensitive to the peptide with a MIC value of $1.1-2.2 \mu \mathrm{M}$.

A study by Bergsson investigated antimicrobial components from the skin mucus of healthy Atlantic cod (Gadus morhua) (Bergsson et al. 2005). Results revealed acidic extracts were active against both Gram-positive and Gram-negative bacteria in conditions that likely mimicked the natural environment of cod. This suggests that the skin mucus layer of the Atlantic cod is an important tissue in surface defenses of cod and most likely protects the fish from infections caused by pathogenic microbes. Antimicrobial test results revealed Bacillus megaterium as the most sensitive to the extract at all concentrations of $\mathrm{NaCl}$. Antimicrobial peptides were identified as histone $\mathrm{H} 2 \mathrm{~B}$ and ribosomal proteins L40, L36A, and L35. Histone-derived peptides originate from both the N-terminus and C-terminus of $\mathrm{H} 1, \mathrm{H} 2 \mathrm{~A}, \mathrm{H} 2 \mathrm{~B}$, and $\mathrm{H} 6$ histones. These histone peptides are found in the skin, skin mucus, and other tissues, including gills, the spleen, and the gut. They are produced in response to epidermal damage, LPS, or certain Gram-negative bacteria. Their antimicrobial activity is broad spectrum against both human and fish pathogens Gram-positive and Gram-negative bacteria, parasites, and fungi (Katzenback 2015).

\section{Anti-Alzheimer's and neuroprotective activity}

Alzheimer's disease is a kind of neurodegenerative disease characterized by progressive loss of neurons. The prevalence of such degenerative neuro-diseases has increased with an increase in life expectancy especially as seen in developed countries (Choi and Choi 2015). Anti-Alzheimer's disease activity is profiled using $\beta$-secretase inhibitory activity. The enzyme $\beta$-secretase along with another enzyme $\Upsilon$-secretase generate a peptide amyloid- $\beta$ (A $\beta$ ) through endo-proteolytic reactions of the amyloid precursor protein (APP) (Choi and Choi 2015). Apolipoprotein enhances the breakdown of beta-amyloid; however, an isoform of apolipoprotein, APOE4, ineffectively breakdowns beta-amyloid and leads to an excess amyloid buildup in the brain. The peptide $A \beta$ molecules can aggregate to form flexible soluble oligomers, some of which turn out misfolded. These misfolded oligomers can induce other $A \beta$ molecules to also take the misfolded oligomeric form (Haass and Selkoe 2007; Nussbaum et al. 2013; Pulawski et al. 2012). Anti-Alzheimer's and neuroprotective activity of fish skin hydrolysates is summarized in Table 4. A $\beta$-secretase inhibitor peptide was purified from skate skin hydrolysate (Lee et al. 2015). The peptide was purified from a neutrase hydrolysate of skate skin on a Sephadex G-25 column and with reversed-phase HPLC. The peptide sequence was determined to be QGYRPLRGPEFL and showed $\beta$-secretase inhibitory activity with an $\mathrm{IC}_{50}$ value of $24.26 \mu \mathrm{M}$. The neuroprotective effect of protein hydrolysates with antioxidant activity from grass carp (Ctenopharyngodon idella) skin was demonstrated (Cai et al. 2015). The hydrolysates at the degree of hydrolysis DH5, DH10, and DH15 showed the most significant neuroprotective effect on 6-OHDAinduced neurotoxicity in MES 23.5. Salmon (Oncorhynchus keta) skin enzymatic hydrolysate showed learning and memory enhancement in mice (Pei et al. 2010). Oxidative stress was alleviated, apoptotic neurons reduced, and brain-derived neurotrophic factor (BDNF) expression was upregulated in treatment groups compared with the control group. Similarly, another study showed that salmon skin collagen peptides reduced oxidative damage and acetylcholinesterase (AChE) while it increased phosphorylated cAMP-response element binding protein ( $\mathrm{p}-\mathrm{CREB}$ ) and BDNF expression in mice (Xu et al. 2015).

\section{Other biological activities}

Other biological activities including antihyperglycemic, MMP inhibitory activity, and adipogenic regulatory have been demonstrated using fish skin as shown in Table 5. Antihyperglycemic activity of fish skin was evaluated 
Table 4 Anti-Alzheimer's and neuroprotective activity of peptides purified from fish skin

\begin{tabular}{llll}
\hline Activity or mechanism & Species & Peptide sequence & Reference \\
\hline B-Secretase inhibitory & Skate (Raja kenojei) & QGYRPLRGPEFL & Lee et al. (2015) \\
Anti-acetylcholinesterase & Salmon (Oncorhynchus keta) & - & Xu et al. (2015) \\
Neuroprotection & Grass carp (Ctenopharyngodon idella) & - & Cai et al. (2015) \\
Learning and memory & Salmon (Oncorhynchus keta) & - & Pei et al. (2010) \\
\hline
\end{tabular}

using dipeptidyl peptidase IV (DPP-IV) inhibitory assay. Steelhead (Oncorhynchus mykiss) skin gelatin hydrolysates were prepared, and the hydrolysate of $4 \%$ papain had the highest DPP-IV inhibitory activity $40-45 \%$ (Cheung and Li-Chan 2017). The hydrolysates were purified with ultrafiltration to obtain fraction of less than $3 \mathrm{kDa}$. Two fractions showed $42 \%$ and $44 \%$ DPP-IV inhibitory activity showing that the activity was not influenced by ultrafiltration as the values of the fractions and the whole hydrolysates were similar.

In a similar study, the DPP-IV inhibitory and glucagonlike peptide-1 (GLP-1) stimulating activity of fish skin gelatin from various warm- and cold-water fish skins were evaluated and compared (Wang et al. 2015). Results revealed that the DPP-IV inhibitory activity of gelatin hydrolysates from warm-water fish was greater than that from cold-water fish. Halibut and tilapia skin gelatin hydrolysate (HSGH and TSGH) fractions at a cutoff of $<1.5 \mathrm{kDa}$ UF were used for peptide sequence identification and to compare the in vivo antihyperglycemic effect. MS/MS spectra analysis revealed amino acid sequences of 6 active peptides as SPGSSGPQGFTG, GPVGPAGNPGANGLN, PPGPTGP RGQPGNIGF, IPGDPGPPGPPGP, LPGERGRPGAPGP, and GPKGDRGLPGPPGRDGM. All these peptides possessed the amino acid proline as the second $\mathrm{N}$-terminal residue. Moreover, it has been reported that peptides with DPP-IV inhibitory activity have amino acids proline, tryptophan, alanine, valine, lysine, and aspartate as the second $\mathrm{N}$-terminal residues in their sequences (Lacroix and Li-Chan 2012). The $\mathrm{IC}_{50}$ values against DPP-IV of the purified peptides ranged from 65.4 to $146.7 \mu \mathrm{M}$, and these were comparable to the peptides from other proteins with the $\mathrm{IC}_{50}$ values between 41.9 and $174 \mu \mathrm{M}$ (Huang et al. 2012; Lacroix and Li-Chan 2014; Silveira et al. 2013). Halibut and tilapia skin gelatin hydrolysates (HSGH and TSGH) lowered blood glucose levels of diabetic rats after 28-day administration. The normal rats and diabetic rats treated with HSGH showed similar plasma DPP-IV activity range of $86.6-94.6 \%$ while the diabetic rats treated with TSGH had a significantly lower DPP-IV activity of $71.6 \%$. The effect of peptides on GLP-1 levels was also evaluated. TSGH exhibited the highest increase in the total GLP-1 level (27.81 pM) while HSGH and sitagliptin exhibited a comparable effect on GLP-1 secretion (23.46-23.81 pM) in diabetic rats after 30-day treatment. However, the underlying mechanism of peptide GLP-1 stimulatory activity is not well defined. However, it is has been proposed that the presence of amino acids leucine and glutamic acid can induce GLP-1 secretion (Chen and Reimer 2009; Reimer 2006). Gelatin hydrolysates of warm-water fish skins (TSGH) exhibited greater in vitro and in vivo DPP-IV inhibitory activity in comparison to cold-water fish skins (HSGH). TSGH contained higher imino acid contents which resulted in increased antihyperglycemic activity in STZ-induced diabetic rats.

Fish skin hydrolysates have also been demonstrated to show MMP-1 inhibitory activity and thus have great potential use as cosmeceuticals. Two active peptides from cod skin gelatin hydrolysates (CGH) with anti-photoaging activity were identified (Lu et al. 2017). The peptides were purified from CGH by ion exchange chromatography and RP-HPLC. The peptide sequences were determined using QTOF mass spectrometer as EIGPSGGRGKPGKDGDAGPK and GFSGLDGAKGD. The purified peptides had a MMP-1 inhibitory activity of $16 \%$ and $15 \%$ respectively. The activity of the peptide GFSGLDGAKGD was achieved through the downregulation of MMP-1, p-ERK, and p-p38 while GEIGPSGGRGKPGKDGDAGPK activity was by the downregulation of p-JNK in MAPK signaling pathways. A study by Chen et al. 2016 purified 23 polypeptides

Table 5 Antihyperglycemic and MMP inhibitory activity of peptides purified from fish skin

\begin{tabular}{llll}
\hline Activity or mechanism & Species & Peptide sequence & Reference \\
\hline Antihyperglycemic & Halibut (Hippoglossus stenolepis) & SPGSSGPQGFTG, GPVGPAGNPGANGLN, & Wang et al. (2015) \\
& & PPGPGPRGPGNIGF & \\
& Tilapia (Oreochromis niloticus) & IPGDPGPPGPPGP, LPGERGRPGAPGP, & GPKGDRGPGPPGRGG \\
MMP inhibitory activity & Cod & EIGPSGGRGKPGKDGDAGPK, GFSGLDGAKGD & Lu et al. (2017) \\
& Tilapia (Oreochromis niloticus) & LSGYGP & Sun et al. (2013) \\
& Sutchi catfish (Pangasius hypophthalmus) & LMWCP & Pyun et al. (2012) \\
\hline
\end{tabular}


from cod skin hydrolysates. Amino acid sequences of Gly-Po and Gly-Leu and the amino acid arginine predominated at the C-terminus of the polypeptides. The hydrolysates showed a protective effect against UV-induced photo-damage to collagen. Expression and activities of matrix metalloproteinases (MMP-1, MMP-3, MMP-9) were downregulated through the elevation of tissue inhibitor of matrix metalloproteinases (TIMPs) and suppression of the activation of mitogen-activated protein kinase (MAPK) signaling pathway in the skin of mice treated with the hydrolysate. In another study, the antiphotoaging effect of a peptide LSGYGP purified from tilapia skin (Oreochromis niloticus) was evaluated by Sun et al. 2013. In vivo experiments showed that the peptide improved the skin condition of UV irradiation-induced photoaging mice through its antioxidant activity. Furthermore, the mechanism of action of the same peptide LSGYGP was studied using ultraviolet B (UVB)-induced mouse embryonic fibroblasts (MEFs) (Ma et al. 2018). The peptide reduced the intercellular ROS generation and decreased superoxide dismutase (SOD) activity as well as reduced MMP-1 and MMP-9 activities. Molecular docking simulation analysis showed that the peptide inhibited MMP activities by docking the active sites of MMP-1 and MMP-9. The anti-photoaging effect of a peptide LMWCP purified from catfish skin (Pangasius hypophthalmus) was evaluated both in animal models and in a clinical trial. The peptide downregulated the expression of MMP-3 and MMP-13, while it upregulated the expression of MMP-2 and MMP-9 (Pyun et al. 2012). In the clinical trial results, treatment groups receiving a daily oral dosage of $1000 \mathrm{mg}$ of LMWCP for 12 weeks showed significantly improved skin and less wrinkling in comparison with the placebo group (Kim et al. 2018).

Last but not least, fish skin has also been demonstrated to have adipogenic regulatory activity. The effect of subcritical water-hydrolyzed fish collagen peptide (SWFCP) from tuna skin on the protein levels of the master adipogenic transcription factors C/EBP and PPAR was investigated (Lee et al. 2017). This was done with the aim of evaluating the underlying inhibitory mechanism of SWFCP in the adipogenic differentiation of 3T3-L1 pre-adipocytes. Results revealed that SWFCP downregulated the expression of the key adipogenic target gene and transcription factors in 3T3-L1 pre-adipocytes exposed to MDI. After 8 days of incubation of 3T3-L1 cells with $1 \mu \mathrm{M}$ dexamethasone and $1 \mu \mathrm{g} /$ $\mathrm{ml}$ insulin (MDI) and SWFCP, the expression levels of C/EBP and PPAR protein were greatly reduced compared with cells stimulated with MDI alone. SWFCP was also shown to downregulate the expression of aP2 an adipogenic target gene, hence inhibiting adipogenic differentiation. Furthermore, SWFCP reduced lipogenesis in hepatocytes. This was demonstrated by the use of palmitate-induced intracellular lipid vacuole accumulation visualized by Nile red staining. The palmitateinduced intracellular lipid vacuole accumulation was greatly reduced in the presence of $1 \mathrm{mg} / \mathrm{ml}$ SWFCP. SWFCP significantly affected other obesity-related factors like low serum cholesterol, low serum triglyceride, and low-density lipoprotein; high serum high-density lipoprotein levels; and reduced size of epididymal adipocytes.

\section{Conclusion}

As elaborately discussed in this review, biologically active peptides have been effectively produced through the bioconversion of fish skin. These different peptides with a range of bioactivities such as antihypertensive, antioxidants, antimicrobial, neuroprotection, antihyperglycemic, and anti-aging have been demonstrated in vitro experiments and to an extent in vivo as well. However, further study is required in the preparation of fish skin hydrolysates using the fermentation method for the production of bioactive peptides. In addition, further study is also required, to determine the potential immunomodulation activity of antioxidant peptides, i.e., anti-inflammatory, and anti-allergy and the corresponding cell signaling pathways. More investigations are also required to determine the neuroprotective effect of fish skin hydrolysates especially with protection against amyloid$\beta$-associated neurotoxicity as observed in Alzheimer's disease. Nevertheless, bioactive peptides purified from fish skin can potentially be utilized in the development of pharmaceutical and nutraceutical products.

\section{Abbreviations}

ABTS: 2,2'-Azino-bis (3-ethylbenzothiazoline-6-sulphonic acid);

ACE: Angiotensin-converting enzyme; AMPs: Antimicrobial peptides;

APOE4: Apolipoprotein; APP: Amyloid precursor protein; AB: Amyloid- $\beta$; BDNF: Brain-derived neurotrophic factor; C/EBP: Ccaat (cytosine-cytosineadenosine-adenosine-thymidine)-enhancer-binding proteins; CGK-I: cGMPdependent protein kinase I; Cgmp: Cyclic guanosine 3'5'monophosphate; DCFH-DA: Dichlorofluorescin diacetate; DMI: $1 \mu \mathrm{M}$ : Dexamethasone and $1 \mu \mathrm{g} /$ ml insulin; DMPO: 5,5-Dimethyl-1-pyrroline-N-oxide; DPPH: Diphenyl-2picrylhydrazyl; DPP-IV: Dipeptidyl peptidase IV; EMR: Enzymatic membrane reactor; eNOS: Endothelial nitric oxide synthase; ESI-MS: Electrospray ionization mass spectrometry; ET-1: Endothelin-1; FRAP: Ferric-reducing antioxidant power; GAPDH: Glyceraldehyde-3-phosphate dehydrogenase; HPLC: High-performance liquid chromatography; IP 3: Inositol-1,4,5trisphosphate; LPS: Lipopolysaccharide; MAPK: Mitogen-activated protein kinase; MMP: Matrix metalloproteinase (MMP-1, MMP-3, MMP-9); NO: Nitric oxide; ORAC: Oxygen radical absorbance activity; PPAR-y: Peroxisome proliferator-activated receptor gamma; PUFAs: Polyunsaturated fatty acids; RAS: Renin-angiotensin-aldosterone system; RNS: Reactive nitrogen species; ROS: Reactive oxygen species; RP-HPLC: Reverse phase high-performance liquid chromatography; SDS/PAGE: Sodium dodecyl sulfate polyacrylamide gel electrophoresis; SHR: Spontaneously hypertensive rats; TIMPs: Tissue inhibitor of matrix metalloproteinase

\section{Acknowledgements}

This research was supported by the Marine Biotechnology Program of the Korea Institute of Marine Science and Technology Promotion (KIMST) funded by the Ministry of Oceans and Fisheries (MOF) (No. 20140441). 


\section{Funding}

The design of the study; collection, analysis, and interpretation of the data; and writing of the manuscript were funded by a grant from the Ministry of Oceans and Fisheries (MOF) (No. 20140441).

\section{Availability of data and materials}

Not applicable.

\section{Authors' contributions}

HGB conceived, designed, and also revised the manuscript. RA designed and drafted the manuscript. AUR revised and edited the manuscript. All authors read and approved the final manuscript.

\section{Ethics approval and consent to participate}

Not applicable.

\section{Consent for publication}

Not applicable.

\section{Competing interests}

The authors declare that they have no competing interests.

\section{Publisher's Note}

Springer Nature remains neutral with regard to jurisdictional claims in published maps and institutional affiliations.

\section{Received: 28 February 2019 Accepted: 8 May 2019}

\section{Published online: 23 May 2019}

\section{References}

Abdelhedi O, Nasri R, Mora L, Toldrá F, Nasri M, Jridi M. Collagenous proteins from black-barred halfbeak skin as a source of gelatin and bioactive peptides. Food Hydrocoll. 2017;70:123-33.

Adessi C, Soto C. Converting a peptide into a drug: strategies to improve stability and bioavailability. Curr Med Chem. 2002;16:963-78.

Bergsson G, Agerberth B, Jörnvall H, Gudmundsson GH. Isolation and identification of antimicrobial components from the epidermal mucus of Atlantic cod (Gadus morhua). FEBS J. 2005;19:4960-9.

Bernardini RD, Harnedy P, Bolton D, Kerry J, O'Neill E, Mullen AM, et al. Antioxidant and antimicrobial peptidic hydrolysates from muscle protein sources and by-products. Food Chem. 2011:4:1296-307.

Bueno-Solano C, López-Cervantes J, Campas-Baypoli ON, Lauterio-García R, AdanBante NP, Sánchez-Machado DI. Chemical and biological characteristics of protein hydrolysates from fermented shrimp by-products. Food Chem. 2009; 3:671-5.

Byun HG, Kim SK. Structure and activity of angiotensin I converting enzyme inhibitory peptides derived from Alaskan pollack skin. J Biochem Mol Biol. 2002;35:239-43.

Cai L, Wu X, Zhang Y, Li X, Ma S, Li J. Purification and characterization of three antioxidant peptides from protein hydrolysate of grass carp (Ctenopharyngodon idella) skin. J Funct Foods. 2015;16:234-42.

Camargo ACM, lanzer D, Guerreiro JR, Serrano SMT. Bradykinin-potentiating peptides: beyond captopril. Toxicon. 2012;4:516-23.

Campoverde C, Milne DJ, Estévez A, Duncan N, Secombes CJ, Andree KB. Ontogeny and modulation after PAMPs stimulation of $\beta$-defensin, hepcidin, and piscidin antimicrobial peptides in meagre (Argyrosomus regius). Fish Shellfish Immunol. 2017:69:200-10

Carrasco-Castilla J, Hernández-Álvarez AJ, Jiménez-Martínez C, Jacinto-Hernández C, Alaiz M, Girón-Calle J, et al. Antioxidant and metal chelating activities of peptide fractions from phaseolin and bean protein hydrolysates. Food Chem. 2012;135:1789-95.

Chalamaiah M, Dinesh Kumar B, Hemalatha R, Jyothirmayi T. Fish protein hydrolysates: proximate composition, amino acid composition, antioxidant activities and applications: a review. Food Chem. 2012;135:3020-38.

Chaud MV, Izumi C, Nahaal Z, Shuhama T, Pires Bianchi MDL, De Freitas O. Iron derivatives from casein hydrolysates as a potential source in the treatment of iron deficiency. J Agric Food Chem. 2002;50:871-7.

Chen Q, Reimer RA. Dairy protein and leucine alter GLP-1 release and mRNA of genes involved in intestinal lipid metabolism in vitro. Nutrition. 2009; 25:340-9.
Chen T, Hou H, Fan Y, Wang S, Chen Q, Si L, et al. Protective effect of gelatin peptides from pacific cod skin against photoaging by inhibiting the expression of MMPs via MAPK signaling pathway. J Photochem Photobiol B Biol. 2016;165:34-41.

Cheung HS, Wang FL, Ondetti MA, Sabo EF, Cushman DW. Binding of peptide substrates and inhibitors of angiotensin-converting enzyme. Importance of the COOH-terminal dipeptide sequence. J Biol Chem. 1980;255:401-5.

Cheung IWY, Li-Chan ECY. Enzymatic production of protein hydrolysates from steelhead (Oncorhynchus mykiss) skin gelatin as inhibitors of dipeptidylpeptidase IV and angiotensin-I converting enzyme. J Funct Foods. 2017;28: 254-64.

Chi CF, Wang B, Hu FY, Wang YM, Zhang B, Deng SG, et al. Purification and identification of three novel antioxidant peptides from protein hydrolysate of bluefin leatherjacket (Navodon septentrionalis) skin. Food Res Int. 2015;73:124-9.

Choi D-Y, Choi H. Natural products from marine organisms with neuroprotective activity in the experimental models of Alzheimer's disease, Parkinson's disease and ischemic brain stroke: their molecular targets and action mechanisms. Arch Pharm Res. 2015:38:139-70.

Choonpicharn S, Jaturasitha S, Rakariyatham N, Suree N, Niamsup H. Antioxidant and antihypertensive activity of gelatin hydrolysate from Nile tilapia skin. J Food Sci Technol. 2015;52:3134-313.

Cole AM, Weis P, Diamond G. Isolation and characterization of pleurocidin, an antimicrobial peptide in the skin secretions of winter flounder. J Biol Chem. 1997;272:12008-13.

Conlon JM. Purification of naturally occurring peptides by reversed-phase HPLC Nat Protoc England. 2007;2(1):191-7.

Cushman DW, Cheung HS. Spectrophotometric assay and properties of the angiotensin-converting enzyme of rabbit lung. Biochem Pharmacol. 1971;20: $1637-48$

Daiber A, Münzel T. Organic nitrate therapy, nitrate tolerance, and nitrateinduced endothelial dysfunction: emphasis on redox biology and oxidative stress. Antioxid Redox Signal. 2015;23:899-942.

Dessy C, Feron O. Pathophysiological roles of nitric oxide: in the heart and the coronary vasculature. Curr Med Chem Anti-inflamm Anti-Allergy Agents. 2004:3:207-16.

Dezsi L. Fibrinolytic actions of ACE inhibitors: a significant plus beyond antihypertensive therapeutic effects. Cardiovasc Res. 2000:47:642-4.

Elias RJ, Kellerby SS, Decker EA. Antioxidant activity of proteins and peptides. Crit Rev Food Sci Nutr. 2008:48:430-41.

Fahmi A, Morimura S, Guo HC, Shigematsu T, Kida K, Uemura Y. Production of angiotensin I converting enzyme inhibitory peptides from sea bream scales. Process Biochem. 2004;39:1 195-200

Fang B, Sun J, Dong P, Xue C, Mao X. Conversion of turbot skin wastes into valuable functional substances with an eco-friendly fermentation technology. J Clean Prod. 2017;156:367-77.

Garner B, Witting PK, Waldeck AR, Christison JK, Raftery M, Stocker P. Oxidation of high density lipoproteins - I. Formation of methionine sulfoxide in apolipoproteins Al and All is an early event that accompanies lipid peroxidation and can be enhanced by alpha-tocopherol. J Biol Chem. 1998; 273:6080-7.

Giri A, Osako K, Okamoto A, Okazaki E, Ohshima T. Antioxidative properties of aqueous and aroma extracts of squid miso prepared with Aspergillus oryzaeinoculated koji. Food Res Int. 2011;44:317-25.

Guang C, Phillips RD. Plant food-derived angiotensin I converting enzyme inhibitory peptides. J Agric Food Chem. 2009;57:b5113-20.

Haass C, Selkoe DJ. Soluble protein oligomers in neurodegeneration: lessons from the Alzheimer's amyloid $\beta$-peptide. Nat Rev Mol Cell Biol. 2007;8:101-12.

Halim NRA, Yusof HM, Sarbon NM. Functional and bioactive properties of fish protein hydolysates and peptides: a comprehensive review. Trends Food Sci Technol. 2016;51:24-33.

Hara H, Funabiki R, Iwata M, Yamazaki K. Portal absorption of small peptides in rats under unrestrained conditions. J Nutr. 1984;114:1122-9.

Hartmann R, Meisel H. Food-derived peptides with biological activity: from research to food applications. Curr Opin Biotechnol. 2007;18:163-9.

Huang CY, Wu CH, Yang Jl, Li YH, Kuo JM. Evaluation of iron-binding activity of collagen peptides prepared from the scales of four cultivated fishes in Taiwan. J Food Drug Anal. 2015;23:671-8.

Huang SL, Jao CL, Ho KP, Hsu KC. Dipeptidyl-peptidase IV inhibitory activity of peptides derived from tuna cooking juice hydrolysates. Peptides. 2012;35:114-21. 
Iwaniak A, Minkiewicz P, Darewicz M. Food-originating ACE inhibitors, including antihypertensive peptides, as preventive food components in blood pressure reduction. Compr Rev Food Sci Food Saf. 2014;13:114-34.

Jongjareonrak A, Benjakul S, Visessanguan W, Nagai T, Tanaka M. Isolation and characterisation of acid and pepsin-solubilised collagens from the skin of Brownstripe red snapper (Lutjanus vitta). Food Chem. 2005;93:475-84.

Jridi M, Nasri R, Lassoued I, Souissi N, Mbarek A, Barkia A, et al. Chemical and biophysical properties of gelatins extracted from alkali-pretreated skin of cuttlefish (Sepia officinalis) using pepsin. Food Res Int. 2013;54:1680-7.

Katzenback B. Antimicrobial peptides as mediators of innate immunity in teleosts. Biology (Basel). 2015:4:607-39.

Kaur C, Kapoor HC. Antioxidants in fruits and vegetables-the millennium's health. Int J Food Sci Technol. 2001;36:703-25.

Kearney PM, Whelton M, Reynolds K, Muntner P, Whelton PK, He J. Global burden of hypertension: analysis of worldwide data. Lancet. 2005;365:217-23.

Kembhavi AA, Kulkarni A, Pant A. Salt-tolerant and thermostable alkaline protease from Bacillus subtilis NCIM No. 64. Appl Biochem Biotechnol. 1993;38:83-92.

Kim DU, Chung HC, Choi J, Sakai Y, Lee BY. Oral intake of low-molecular-weight collagen peptide improves hydration, elasticity, and wrinkling in human skin: a randomized, double-blind, placebo-controlled study. Nutrients. 2018;10:826.

Kim SK, Mendis E. Bioactive compounds from marine processing byproducts - a review. Food Res Int. 2006;39:383-93.

Kim SK, Ravichandran YD, Khan SB, Kim YT. Prospective of the cosmeceuticals derived from marine organisms. Biotechnol Bioprocess Eng. 2008;13:511-23.

Kim SK, Wijesekara I. Development and biological activities of marine-derived bioactive peptides: a review. J Funct Foods. 2010;2:1-9.

Kleekayai T, Harnedy PA, O'Keeffe MB, Poyarkov AA, Cunhaneves A, Suntornsuk $W$, et al. Extraction of antioxidant and ACE inhibitory peptides from Thai traditional fermented shrimp pastes. Food Chem. 2015;176:441-7.

Korhonen H, Pihlanto A. Food-derived bioactive peptides--opportunities for designing future foods. Curr Pharm Des. 2003;9:1297-308.

Lacroix IME, Li-Chan ECY. Evaluation of the potential of dietary proteins as precursors of dipeptidyl peptidase (DPP)-IV inhibitors by an in silico approach. J Funct Foods. 2012;4:403-22.

Lacroix IME, Li-Chan ECY. Isolation and characterization of peptides with dipeptidyl peptidase-IV inhibitory activity from pepsin-treated bovine whey proteins. Peptides. 2014;54:39-48.

Lassoued I, Jridi M, Nasri R, Dammak A, Hajji M, Nasri M, et al. Characteristics and functional properties of gelatin from thornback ray skin obtained by pepsinaided process in comparison with commercial halal bovine gelatin. Food Hydrocoll. 2014;41:309-18.

Lassoued I, Mora L, Nasri R, Jridi M, Toldrá F, Aristoy MC, et al. Characterization and comparative assessment of antioxidant and ACE inhibitory activities of thornback ray gelatin hydrolysates. J Funct Foods. 2015;13:225-38.

Lau CC, Abdullah N, Shuib AS, Aminudin N. Novel angiotensin I-converting enzyme inhibitory peptides derived from edible mushroom Agaricus bisporus (J.E. Lange) Imbach identified by LC-MS/MS. Food Chem. 2014;148:396-401.

Lee EJ, Hur J, Ham SA, Jo Y, Lee SY, Choi MJ, et al. Fish collagen peptide inhibits the adipogenic differentiation of preadipocytes and ameliorates obesity in high fat diet-fed mice. Int J Biol Macromol. 2017;104:281-6.

Lee JK, Jeon JK, Byun HG. Effect of angiotensin I converting enzyme inhibitory peptide purified from skate skin hydrolysate. Food Chem. 2011;125:495-9.

Lee JK, Jeon JK, Byun HG. Antihypertensive effect of novel angiotensin I converting enzyme inhibitory peptide from chum salmon (Oncorhynchus keta) skin in spontaneously hypertensive rats. J Funct Foods. 2014;7:381-9.

Lee JK, Li-Chan ECY, Byun H-G. Characterization of $\beta$-secretase inhibitory peptide purified from skate skin protein hydrolysate. Eur Food Res Technol. 2015;240:129-36.

Lee SH, Song KB. Purification of an iron-binding nona-peptide from hydrolysates of porcine blood plasma protein. Process Biochem. 2009;44:378-81.

Lee SH, Qian ZJ, Kim SK. A novel angiotensin I converting enzyme inhibitory peptide from tuna frame protein hydrolysate and its antihypertensive effect in spontaneously hypertensive rats. Food Chem. 2010;118:96-102.

Lu J, Hou H, Fan Y, Yang T, Li B. Identification of MMP-1 inhibitory peptides from cod skin gelatin hydrolysates and the inhibition mechanism by MAPK signaling pathway. J Funct Foods. 2017;33:251-60.

Ma Q, Liu Q, Yuan L, Zhuang Y. Protective effects of LSGYGP from fish skin gelatin hydrolysates on UVB-induced MEFs by regulation of oxidative stress and matrix metalloproteinase activity. Nutrients. 2018;10:420.

Mahboob S. Isolation and characterization of collagen from fish waste materialskin, scales and fins of Catla catla and Cirrhinus mrigala. J Food Sci Technol. 2014;52:4296-305.
Majumdar RK, Roy D, Bejjanki S, Bhaskar N. Chemical and microbial properties of shidal, a traditional fermented fish of Northeast India. J Food Sci Technol. 2016:53:401-10.

Mendis E, Rajapakse N, Byun HG, Kim SK. Investigation of jumbo squid (Dosidicus gigas) skin gelatin peptides for their in vitro antioxidant effects. Life Sci. 2005a;77:2166-78.

Mendis E, Rajapakse N, Kim SK. Antioxidant properties of a radical-scavenging peptide purified from enzymatically prepared fish skin gelatin hydrolysate. $J$ Agric Food Chem. 2005b;53:581-7.

Nagarajan M, Benjakul S, Prodpran T, Songtipya P, Kishimura H. Characteristics and functional properties of gelatin from splendid squid (Loligo formosana) skin as affected by extraction temperatures. Food Hydrocoll. 2012;29:389-97.

Nakajima H, Itakura M, Kubo T, Kaneshige A, Harada N, Izawa T, et al. Glyceraldehyde-3-phosphate dehydrogenase (GAPDH) aggregation causes mitochondrial dysfunction during oxidative stress-induced cell death. J Biol Chem. 2017;292:4727-42.

Ngo DH, Kang KH, Jung WK, Byun HG, Kim SK. Protective effects of peptides from skate (Okamejei kenojei) skin gelatin against endothelial dysfunction. J Funct Foods. 2014a;10:243-51.

Ngo DH, Kang KH, Ryu B, Vo TS, Jung WK, Byun HG, et al. Angiotensin-I converting enzyme inhibitory peptides from antihypertensive skate (Okameje kenojei) skin gelatin hydrolysate in spontaneously hypertensive rats. Food Chem. 2014b;174:37-43.

Ngo DH, Qian ZJ, Ryu B, Park JW, Kim SK. In vitro antioxidant activity of a peptide isolated from Nile tilapia (Oreochromis niloticus) scale gelatin in free radicalmediated oxidative systems. J Funct Foods. 2010;2:107-17.

Ngo DH, Ryu B, Vo TS, Himaya SWA, Wijesekara I, Kim SK. Free radical scavenging and angiotensin-I converting enzyme inhibitory peptides from Pacific cod (Gadus macrocephalus) skin gelatin. Int J Biol Macromol. 2011;49:1110-6.

Ngo DH, Vo TS, Ryu BM, Kim SK. Angiotensin-l-converting enzyme (ACE) inhibitory peptides from Pacific cod skin gelatin using ultrafiltration membranes. Process Biochem. 2016;51:1622-8.

Nikoo M, Benjakul S, Xu X. Antioxidant and cryoprotective effects of Amur sturgeon skin gelatin hydrolysate in unwashed fish mince. Food Chem. 2015; 181:295-303.

Nussbaum JM, Seward ME, Bloom GS. Alzheimer disease: a tale of two prions. Prion. 2013;7:14-9.

Paul M. Physiology of local renin-angiotensin systems. Physiol Rev. 2006;86:747-803.

Pei X, Yang R, Zhang Z, Gao L, Wang J, Xu Y, et al. Marine collagen peptide isolated from Chum Salmon (Oncorhynchus keta) skin facilitates learning and memory in aged C57BL/6J mice. Food Chem. 2010;118:333-40.

Pihlanto-Leppälä A. Bioactive peptides derived from bovine whey proteins. Trends Food Sci Technol. 2000;11:347-56.

Pomponi SA. The bioprocess-technological potential of the sea. Prog Ind Microbiol. 1999:35:5-13.

Power $\mathrm{O}$, Nongonierma AB, Jakeman P, Fitzgerald RJ. Food protein hydrolysates as a source of dipeptidyl peptidase IV inhibitory peptides for the management of type 2 diabetes. Proc Nutr Soc. 2014;73:34-46.

Pulawski W, Ghoshdastider U, Andrisano V, Filipek S. Ubiquitous amyloids. Appl Biochem Biotechnol. 2012;166:1626-43.

Pyun HB, Kim M, Park J, Sakai Y, Numata N, Shin JY, et al. Effects of collagen tripeptide supplement on photoaging and epidermal skin barrier in UVBexposed hairless mice. Prev Nutr Food Sci. 2012;17:245-53.

Reimer RA. Meat hydrolysate and essential amino acid-induced glucagon-like peptide-1 secretion, in the human $\mathrm{NCl}-\mathrm{H} 716$ enteroendocrine cell line, is regulated by extracellular signal-regulated kinase $1 / 2$ and p38 mitogenactivated protein kinases. J Endocrinol Soc Endocrinol. 2006;19:1159-70.

Rho SJ, Lee JS, Chung YI, Kim YW, Lee HG. Purification and identification of an angiotensin I-converting enzyme inhibitory peptide from fermented soybean extract. Process Biochem. 2009:44:490-3.

Rogerson FM, Chai SY, Schlawe I, Murray WK, Marley PD, Mendelsohn FA. Presence of angiotensin converting enzyme in the adventitia of large blood vessels. J Hypertens. 1992;10:615-20.

Rui X, Boye Jl, Simpson BK, Prasher SO. Purification and characterization of angiotensin I-converting enzyme inhibitory peptides of small red bean (Phaseolus vulgaris) hydrolysates. J Funct Foods. 2013;5:1116-24.

Sae-Leaw T, Karnjanapratum S, O'Callaghan YC, O'Keeffe MB, FitzGerald RJ, O'Brien NM, et al. Purification and identification of antioxidant peptides from gelatin hydrolysate of seabass skin. J Food Biochem. 2017:41:e12350.

Saiga A, Tanabe S, Nishimura T. Antioxidant activity of peptides obtained from porcine myofibrillar proteins by protease treatment. J Agric Food Chem. 2003;51:3661-7. 
Sampath Kumar NS, Nazeer RA, Jaiganesh R. Purification and identification of antioxidant peptides from the skin protein hydrolysate of two marine fishes, horse mackerel (Magalaspis cordyla) and croaker (Otolithes ruber). Amino Acids. 2012:5:1641-9.

Seo JK, Lee MJ, Go HJ, Kim YJ, Park NG. Antimicrobial function of the GAPDHrelated antimicrobial peptide in the skin of skipjack tuna, Katsuwonus pelamis. Fish Shellfish Immunol. 2014;36:571-81.

Seo JK, Lee MJ, Go HJ, Park TH, Park NG. Purification and characterization of YFGAP, a GAPDH-related novel antimicrobial peptide, from the skin of yellowfin tuna, Thunnus albacares. Fish Shellfish Immunol. 2012;33:743-52.

Silva RSG, Bandeira SF, Pinto LAA. Characteristics and chemical composition of skins gelatin from cobia (Rachycentron canadum). LWT Food Sci Technol. 2014;57:580-5.

Silveira ST, Martínez-Maqueda D, Recio I, Hernández-Ledesma B. Dipeptidyl peptidase-IV inhibitory peptides generated by tryptic hydrolysis of a whey protein concentrate rich in $\beta$-lactoglobulin. Food Chem. 2013;141:1072-7.

Singh P, Benjakul S, Magsood S, Kishimura H. Isolation and characterisation of collagen extracted from the skin of striped catfish (Pangasianodon hypophthalmus). Food Chem. 2011;124:97-105.

Su Y. Isolation and identification of pelteobagrin, a novel antimicrobial peptide from the skin mucus of yellow catfish (Pelteobagrus fulvidraco). Comp Biochem Physiol B Biochem Mol Biol. 2011;158:149-54.

Sun L, Zhang Y, Zhuang Y. Antiphotoaging effect and purification of an antioxidant peptide from tilapia (Oreochromis niloticus) gelatin peptides. Funct Foods. 2013;5:154-62.

Theodore AE, Raghavan S, Kristinsson HG. Antioxidative activity of protein hydrolysates prepared from alkaline-aided channel catfish protein isolates. J Agric Food Chem. 2008:56:7459-66.

Thuanthong M, De Gobba C, Sirinupong N, Youravong W, Otte J. Purification and characterization of angiotensin-converting enzyme-inhibitory peptides from Nile tilapia (Oreochromis niloticus) skin gelatine produced by an enzymatic membrane reactor. J Funct Foods. 2017;36:243-54.

Wang L, An X, Yang F, Xin Z, Zhao L, Hu Q. Isolation and characterisation of collagens from the skin, scale and bone of deep-sea redfish (Sebastes mentella). Food Chem. 2008;108:616-23.

Wang TY, Hsieh CH, Hung CC, Jao CL, Chen MC, Hsu KC. Fish skin gelatin hydrolysates as dipeptidyl peptidase IV inhibitors and glucagon-like peptide1 stimulators improve glycaemic control in diabetic rats: a comparison between warm- and cold-water fish. J Funct. 2015;19:330-40.

Wu H, Liu Z, Zhao Y, Zeng M. Enzymatic preparation and characterization of ironchelating peptides from anchovy (Engraulis japonicus) muscle protein. Food Res Int. 2012;48:435-41.

Wu Q, Jia J, Yan H, Du J, Gui Z. A novel angiotensin-l converting enzyme (ACE) inhibitory peptide from gastrointestinal protease hydrolysate of silkworm pupa (Bombyx mori) protein: biochemical characterization and molecular docking study. Peptides. 2015;68:17-24.

Wu W, Li B, Hou H, Zhang H, Zhao X. Identification of iron-chelating peptides from Pacific cod skin gelatin and the possible binding mode. J Funct Foods. 2017;35:418-27.

Xu L, Dong W, Zhao J, Xu Y. Effect of marine collagen peptides on physiological and neurobehavioral development of male rats with perinatal asphyxia. Mar Drugs. 2015;13:3653-71.

Yamamoto N, Akino A, Takano T. Antihypertensive effect of the peptides derived from casein by an extracellular proteinase from Lactobacillus helveticus CP790. J Dairy Sci. 1994;77:917-22.

Zhang Y, Duan X, Zhuang Y. Purification and characterization of novel antioxidant peptides from enzymatic hydrolysates of tilapia (Oreochromis niloticus) skin gelatin. Peptides. 2012;38:13-21.

\section{Ready to submit your research? Choose BMC and benefit from}

- fast, convenient online submission

- thorough peer review by experienced researchers in your field

- rapid publication on acceptance

- support for research data, including large and complex data types

- gold Open Access which fosters wider collaboration and increased citations

- maximum visibility for your research: over $100 \mathrm{M}$ website views per year

At BMC, research is always in progress.

Learn more biomedcentral.com/submissions 